\title{
Synthesis of Vitamins by Micro-organisms of the Alimentary Tract
}

\author{
Dr. S. K. Kon (National Institute for Research in Dairying, \\ University of Reading)
}

\section{Synthesis in Ruminants}

The discovery that ruminants can be maintained for long periods of time on a diet very low in certain vitamins came at a surprisingly early stage of what one may now call the heroic period in the history of these factors; nearly 30 years have passed since Theiler, Green and Viljoen (1915) recorded this observation, and in describing it wrote in a truly prophetic fashion: "We . . . think it at least possible that the vitamine requirements of cattle are so low that they may even be covered indirectly by synthesis carried out by the extensive bacterial flora of the intestines".

Eleven years later Bechdel, Eckles and Palmer (1926) showed that heifer calves could grow to maturity and reproduce on a ration which contained insufficient "vitamin B" to support the growth of young rats for more than 2 to 4 weeks. They incidentally found that the apparent immunity of the calf to deprivation of vitamins did not extend to vitamin A and confirmed the earlier opinion of Hart, Steenbock, Humphrey and Hulce (1924-25) that this factor is indispensable in ruminant nutrition. In further work Bechdel and Honeywell (1927) found that the milk of their experimental animals contained normal quantities of "vitamin B". They agreed that the hypothesis of bacterial synthesis originally advanced by the South African workers was the most likely explanation of all their findings, and proceeded to a direct experimental proof of their views.

Before examining this evidence it might be opportune to describe very briefly the peculiarities of digestion in the ruminant. Swallowed food reaches first the rumen or paunch, a large organ of a capacity in cattle of 30 to 60 gallons, in which the food is submitted to kneading, mixing and soaking and also to vigorous bacterial action of which the most conspicuous is the fermentation of cellulose. The paunch communicates freely with the second stomach or reticulum. At intervals portions of the fermenting contents are returned to the mouth for renewed mastication and addition of saliva; the animal cheweth the cud. The cud is swallowed again and, if fine enough, passes into the omasum or third stomach, also called the manyplies. This compartment acts as a strainer and from it the finely dispersed fodder gets into the fourth stomach or abomasum which is the true digestive stomach, secreting gastrio juice and where the contents attain a $p H$ of from 2 to 4 . The further portions of the alimentary tract, the small and large intestine, are roughly the same in ruminants and in simple stomached animals; in these latter, however, and especially in herbivora, the caecum and colon fulfil the storage and fermentation function of the paunch. The notable fact is that in ruminants the main bacterial action takes place before, in other animals after, thè passage of food through the true stomach.

Bechdel, Honeywell, Dutcher and Knutsen (1927, 1928) made an opening or fistula into the paunch of one of their heifers which for nearly 3 years had received the ration deficient in the vitamin $\mathbf{B}$.complex. voL. 3,1945$]$ 
Through this opening samples of contents were removed. Tests with rats showed that the food mass was now a potent source of the $B$ vitamins. Moreover a bacterium of the genus Flavobacterium present in large profusion in the rumen was isolated in pure culture and, when grown on synthetic media, proved to be a rich source of the vitamin $B$ complex. Though the assumption that Flavobacterium vitarumen, as the organism was called, was alone largely responsible for the supply of the vitamin B complex to the cow, was too optimistic in its simplicity, later work proved the fundamental soundness of the findings of the Pennsylvania workers.

In the 10 odd years following the publications of Bechdel and his colleagues much progress was made in the identification of various members of the vitamin B complex and in methods of testing. The newer investigations were carried out almost simultaneously at the Agricultural Experiment Stations of California (McElroy and Goss, 1939, 1940, 1, 2, 3, 1941, 1, 2; McElroy and Jukes, 1940), Wisconsin (Lardinois, Mills, Elvehjem and Hart, 1944; Wegner, Booth, Elvehjem and Hart, 1940, 1941) and Ohio (Hunt, Burroughs, Bethke, Schalk and Gerlaugh, 1943; Hunt, Kick, Burroughs, Bethke, Schalk and Gerlaugh, 1941). The procedures were on the whole the same, and deficient diets of the synthetic type were mostly used, though natural foods also were given. The concentration of various members of the vitamin B complex was determined in the diet and again in sampled portions of the rumen contents obtained through a fistula or after slaughter; with milch cows the milk also was examined. The results uniformly indicated that the contents of the rumen were, on the dry weight basis, substantially richer than the diet in riboflavin, vitamin $\mathbf{B}_{6}$, pantothenic acid, nicotinic acid, biotin and vitamin $\mathrm{K}$. Corroborative evidence of synthesis of nicotinic acid by ruminants was forthcoming also from another laboratory (Pearson, Schmidt and Mackey, 1939). The increases in some cases were as high as eighty to one hundredfold and the secretion in the milk of 10 times the ingested amount of riboflavin and $2 \frac{1}{2}$ times that of pantothenic acid was reported also (McElroy and Goss, 1940, 2, 1941, 2).

The evidence for bacterial synthesis, though overwhelming, is not quite direct since concentration of a given vitamin may have taken place in the rumen owing to different rates of passage of different nutrients, while vitamins secreted in the milk may have been synthesized outside the digestive tract. The fact, however, that the increases in the amounts of the various water soluble vitamins in the rumen contents were not all of the same order and especially the stimulating effect on the production of vitamins of the presence of easily available carbohydrate (Hunt, Burroughs, Bethke, Schalk and Gerlaugh, 1943) or of vitamin $B_{1}$ (Wegner, Booth, Elvehjem and Hart, 1940), speaks very strongly in favour of synthesis by intestinal bacteria of the factors just enumerated. The position regarding vitamin $B_{1}$ is curious. Though some observers noticed an increase (Wegner, Booth, Elvehjem and Hart, 1940; Johnson, Maynard and Loosli, 1941) or detected the presence of vitamin $B_{1}$ in the rumen contents of an animal which had subsisted for several months on a diet deficient in this factor (McElroy and Goss, 1941, 1), others failed to find evidence of synthesis (Hunt, Burroughs, Bethke, Schalk and Gerlaugh, 1943; Hunt, Kick, Burroughs, Bethke, Schalk and Gerlaugh, 1941; Lardinois, Mills, Elvehjem and Hart, 1944). That the cow is independent 
of an exogenous supply of vitamin $B_{1}$ has been proved beyond any doubt. It is possible, however, that this is, like vitamin $\mathrm{C}$, synthesized outside the rumen, or, if synthesized in the rumen, it may be rapidly removed from it or destroyed after formation (Hunt, Kick, Burroughs, Bethke, Schalk and Gerlaugh, 1941).

I have already mentioned that the ability of the flora of the rumen to synthesize vitamins depends on the environment and that apparently the activity of the organisms may be fostered or depressed according to the availability of bacterial nutrients. It has been pointed out (Savage and McCay, 1942) that in the first weeks of life, before the proper bacterial flora becomes established, the young ruminant must be dependent on an exogenous supply of the vitamin B complex just like the young dog or rat. In fact, the work of Phillips and his colleagues (Lundquist and Phillips, 1943; Phillips, Lundquist and Boyer, 1941) shows clearly that nicotinic acid is essential in the diet of the young calf.

Perhaps, because of the nutritional independence of cattle where certain vitamins are concerned, scant regard has in the past been paid to these factors in the agricultural sphere. This attitude has fortunately changed, and in his introductory address to this Society Sir Frederick Hopkins recorded the felicitous example of such conversion of one of our most illustrious members (Hopkins, 1944).

\section{Synthesis in Non-Ruminants}

It stands to reason that the intestinal flora of ruminants is not alone in its ability to synthesize certain vitamins. Numerous workers have demonstrated the presence of "vitamin B" in the excreta of birds and mammals ( $c f$. Kon, Kon and Mattick, 1938), and it has been known since the classical work of Osborne and Mendel (1911) that rats subsisting on a synthetic diet will frequently benefit from consuming their own droppings. In fact, before cages with screens were generally adopted, this possibility was threatening to become a major laboratory nuisance ( $c f$. Kon, Kon and Mattick, 1938).

The literature dealing with the synthesis of vitamins by bacteria is so enormous that I will restrict myself to a reference to recent work from which it is evident that some bacteria including the intestinal $B$. proteus vulgaris can synthesize all known members of the vitamin $B$ complex (Thompson, 1942), and that other intestinal organisms, Bact. coli, B. lactis aerogenes, $B$. faecalis alcaligenes and $B$. mesentericus vulgatus, manufacture at least biotin, riboflavin, vitamin $\mathrm{B}_{1}$ and nicotinic acid (Burkholder and McVeigh, 1942), while Bact. coli produces also vitamin $\mathrm{K}$ (Orla-Jensen, Orla-Jensen, Dam and Glavind, 1941). On the specific point of vitamin synthesis by bacteria isolated from the intestine of the rat the evidence is substantial also (Abdel-Salaam and Leong, 1938), and more recent work indicates the manufacture of biotin in the gut of the rat (Nielsen, Shull and Peterson, 1942) and of inositol in the gut of the mouse (Woolley, 1942); yet the bare fact that for upwards of 30 years countless rats have been used for testing vitamin $B$ in its multiplicity and that nowadays at least 4 separate members of the complex are quantitatively measured by rat tests indicates that normally the contribution of the bacterial flora of the rat to its economy of these factors is quite insufficient to cover the voL. 3, 1945] 
animal's requirements. Apparently the architecture of the rat's gut and the processes of digestion allow of the formation, but not of the uptake, of substantial quantities of the vitamin B complex, though the position regarding vitamin $K$ is probably different (Dam, Schønheyder and Lewis, 1937; Greaves, 1939)

It was therefore with something of a shock that those interested in nutrition learnt suddenly that the worm had turned and that in a Danish laboratory rats had appeared which managed to grow and thrive without "vitamin B" in their food. The phenomenon aptly called refection and ably described by Fridericia (Fridericia, 1926; Fridericia, Freudenthal, Gudjonsson, Johansen and Schoubye, 1927-28) appeared spontaneously in the summer of 1925 in a young rat hitherto declining on a customary "vitamin B" deficient diet containing raw rice starch. The animal suddenly began to grow at a normal rate whilst its faeces became white and bulky owing to the presence of undigested starch. Rice starch has been extensively used in synthetic diets without the appearance of refection which in its spontaneous form must be extremely rare. It is therefore worthy of note that the condition appeared of its own accord in the autumn of 1926 in the laboratories of the Lister Institute (Roscoe, 1927-28); again rats receiving. a diet with raw rice starch and deprived of the vita min B complex were affected. Once established, refection could be tra nsmitted in both laboratories to other rats by the feeding of the bulky white faeces but it should be noted that, as no communication passed between the two laboratories before the outbreak in London, the spontaneity of the latter cannot be questioned.

About the same time we (Kon and Watchorn, 1927-28). decided to study a problem which later proved closely related to classical refection. In a series of papers Randoin and her collaborators (Randoin and Lecoq, 1927 ; Randoin and Simonnet, 1923; 1924, 1, 2, 3, 4, 5; 1925) had shown that with pigeons and rats the rapidity of onset of symptoms of "vitamin B" deficiency depended on the nature of the carbohydrate in the diet. Of these, potato starch exerted the most pronounced sparing action; it also proved the least digestible. The low digestibility of this starch had already been noticed by Langworthy and Deuel (1920). The explanation put forward by Randoin that "vitamin B" is needed only for the metabolism of carbohydrates, and that with potato starch their diets were virtually carbohydrate free, seemed to us rather inadequate; we decided therefore to study the effect on rats of diets devoid of the vitamin B complex but containing potato starch.

With such diets refection, that is the ability to live and grow for indefinite periods without an exogenous supply of the vitamin B complex, became the rule rather than the exception, and, though failures naturally occurred, we were able to produce it in 4 different laboratories on 2 continents (Kon and Watchorn, 1927-28; Kon, 1931; Kon, 1935; Kon, Kon and Mattick, 1938) and the relative ease of the procedure has since been confirmed by several workers (Bliss, 1936; Kelly and Parsons, 1937; Nathan, 1935; Parsons and Kelly, 1935; Parsons, Kelly and Hussemann, 1933). I should mention, just to confirm that coming events cast their shadow before them, that nearly 50 years ago Eijkman (1897) noticed that hens given potato starch instead of polished rice did not develop polyneuritis. 
Difficulties in the production of symptoms of vitamin B deficiency have been noticed sporadically in the biochemical laboratory in Cambridge where potato starch had been intermittently used, and Sir Frederick Hopkins informed us some years ago that he had himself observed this effect (Kon and Watchorn, 1927-28). One is tempted to speculate that perhaps a mild state of refection in the rats used by him in the classic and famous experiments on the accessory food factors (Hopkins, 1912) may account for the dramatic effects of the very small supplements of milk and may afford an explanation of the discrepanoy between his findings and those of Osborne and Mendel $(1918,1920)$ as to the richness of milk in these factors.

I do not think that anybody has yet satisfactorily explained how, in the spontaneous onset of rice starch refection, rats suddenly and largely lose the power to digest the starch, though a curiously analogous condition of starch dyspepsia has been described in man by Hurst and Knott (1930). There is every reason to believe that, apart from this, rice starch refection, once established does not differ materially from potato starch refection, and that both can be explained on the same grounds. The cause can certainly not be attributed to a single property of the refective diet or to an infection with a specific organism. In fact we (Kon, 1935; Kon, Kon and Mattick, 1938) found no spectacular difference in the bacteriological picture of the caecal contents or of the faeces when rats thriving on a refective diet were compared in this respect with rats declining on a vitamin $B$ deficient diet or on the refective diet after its refective properties had been destroyed by gelatinizing the starch. We advanced at the time the following explanation of the phenomenon of established refection. The presence of undigested starch and of requisite starch splitting organisms in the caecum of the rat leads to a vigorous fermentation and results in an acid $p \mathrm{H}$. This coupled with the presence of ample amounts of a nutrient medium allows of more normal and more vigorous growth of the caecal flora than in the alkaline caecum of a vitamin B deficient rat. An acid $p H$ favours the synthesis of members of the vitamin $B$ complex (Hunt, Kick, Burroughs, Bethke, Schalk and Gerlaugh, 1941; Scheunert and Schieblich, 1927). We have clearly shown that the caecal contents of refected rats are, per unit of dry weight, much richer in the vitamin $B$ complex than those of rats subsisting on a non-refective vitamin $B$ deficient diet (Kon, 1935; Kon, Kon and Mattick, 1938). Moreover we think that these increased quantities of the vitamin B complex become available to the refected rat by virtue of the acid $p \mathrm{H}$ of its caecum and that, in fact, it becomes similar in this respect to the ruminant, the caecal region combining the roles of the paunch and of the true stomach. I have advisedly used the term caecal region because surgical removal of the caecum does not prevent starch refection, apparently because compensatory hypertrophy of the adjacent parts of the intestine allows them to carry on its function (Kon, 1935; Kon, Kon and Mattick, 1938).* There is general agreemont among workers on refection that refected rats void much more of the vitamin $B$ complex in the faeces than rats subsisting on diets equally lacking in preformed vitamin B but not

\footnotetext{
* We have recently found it impossible in my laboratory to induce potato starch refection in a group of over 50 caecectomized rats, though normal rats became refected at the same time without difficulty. (Footnote added in proof.)
}

voL. 3,1945$]$ 
refective (Bliss, 1936; Fridericia, Freudenthal, Gudjonsson, Johansen and Sehoubye, 1927-28; Kelly and Parsons, 1937; Kon, 1935; Kon, Kon and Mattick, 1938), though Roscoe (1927-28) considered the vitamin $B_{1}$ content of refected facces to be negligible.

We have just discussed a method evolved by, or imposed by external circumstances on, the rat which makes it at times partly akin to the ruminant in nutritional independence. It may be added that refection has been observed also in the pigeon (Taylor and Thant, 1929). A similarly interesting tale may be told of yet another animal, the rabbit. It was found some 60 years ago by Morot (1882) and has since been confirmed by Madsen (1939), Taylor (1939) and Eden $(1940,1,2)$ that rabbits pass two types of faeces, one normal, voided in the day time, the other of softer consistency produced at night. These faeces literally do not see the light of day as they are seized and swallowed by the rabbit directly from the anus and special devices preventing coprophagy are needed to demonstrate their existence. The day faeces represent less completely digested food debris; the night ones are richer in protein, swarm with bacteria and closely resemble caecal contents in composition. It has not yet been directly proved that the rabbit uses this source as an additional, or perhaps main, supply of the vitamin B complex; circumstantial evidence is almost as strong as that of the trout in the milk.

Evidence has been accumulating that the synthetic activities of intestinal bacteria supply their non-ruminant hosts with a certain modicum of various vitamins even in the absence of frank refection and that the observed exogenous requirements of various species for different members of the vitamin B complex, and also for vitamin $\mathrm{K}$ represent only the excess of the true needs over the amounts derived from endogenous sources. The evidence is partly based on the behaviour of caecectomized rats (Guerrant, Dutcher and Tomey, 1935; Taylor, Pennington and Thacker, 1942; $c f$. however, Griffith, 1935), partly on differences in response to vitamin deficient diets containing different carbohydrates (cf. for example Guerrant, Dutcher and Tomey, 1935; Morgan, Cook and Davison, 1938; Mannering, Orsini and Elvehjem, 1944; and the work already quoted of Randoin) and partly on ingenious balance experiments like those of Mitchell and Isbell (1942). The main weight of evidence, however, comes from recent work based on a new technique which makes use of the bacteriostatic action of sulphonamides.

\section{Inhibition of Synthesis by Sulphonamide Drugs}

While it is obviously impossible to discuss even briefly the effects of these drugs on bacteria it might be helpful to point out that the present theory of their action, evolved from the pioneering work of Woods (1940) and Fildes (1940), suggests that it consists in the inhibition of one or more bacterial enzyme systems. Para-aminobenzoic acid, a substance occurring naturally, and structurally related to the sulphonamides, antagonizes their action by direct competition for the enzyme. That much is generally accepted, though the full role of para-aminobenzoic acid in bacterial metabolism is still a matter of controversy (Henry, 1943).

Recent work has disclosed further examples of such competition by inhibitors sufficiently related to essential bacterial metabolites to fit the same enzyme yet not sufficiently related to them to act as substitutes. 
Thus pantoyltaurine and pantothenic acid (McIlwain, 1942; Robinson, 1944; Snell, 1941), pyri-aneurin and aneurin (Woolley and White, 1943, 1), pyridine- $\beta$-sulphonic acid and nicotinic acid (McIlwain, 1940) form such antagonistic pairs. Such antagonisms cover not only bacterial relationships but in a few instances extend directly to the utilization of certain vitamins by animals. Thus West (1941) made the interesting observation, confirmed by Schaefer, McKibbin and Elvehjem (1942), that sulphapyridine interfered with the curative action of nicotinic acid in dogs deprived of it, while Emerson and Tishler (1944) detected a similar effect of isoriboflavin in rats receiving suboptimal amounts of riboflavin, and Woolley and White $(1943,1)$ produced vitamin $B_{1}$ deficiency in mice with the pyridine analogue of aneurin. Observations of a like nature by Snell, Chan, Spirodanoff and Way (1943) regarding the production of pantothenic acid deficiency in mice by administration of thiopantothenic acid were, however, not confirmed by Unna (1943) or by Woolley and White $(1943,2)$.

of greater importance than these direct effects, and more relevant to the problem under discussion, are indirect effects on the vitamin economy of the animal brought about by the interference of sulphonamides with its intestinal flora. For this purpose sulphaguanidine and succinylsulphathiazole, 2 drugs of low toxicity and little absorbed from the gut, are particularly suitable. Their general effect is to decrease the rate of growth of rats subsisting on purified synthetic diets supplemented with crystalline vitamins known to be essential (Black, McKibbin and Elvehjem, 1941; Black, Overman, Elvehjem and Link, 1942; Daft, Ashburn and Sebrell, 1942; Daft, Ashburn, Spicer and Sebrell, 1942; Dann, 1941; Kornberg, Daft and Sebrell, 1943; Light, Cracas, Olcott and Frey, 1942; Mackenzie, Mackenzie and McCollum, 1941; Martin, 1942, 1, 2; Neumann, Krider and Day, 1943; Nielsen and Black, 1944; Nielsen and Elvehjem, 1942; Ransone and Elvehjem, 1943; Spicer, Daft, Sebrell and Ashburn, 1942; Totter and Day, 1943; Welch, 1942; Welch and Wright, 1943; West, Jefferson and Rivera, 1943). In addition, certain specific effects are elicited, varying in nature with changes in the composition of the basal diet and supplements. For example, Black, Overman, Elvehjem and Link (1942) observed in rats a prolongation of the prothrombin time which could be prevented or cured by the administration of vitamin $\mathbf{K}$, and these findings have been confirmed by other authors (Day, Wakim, Krider and O'Bannion, 1943; Kornberg, Daft and Sebrell, 1944; Wakim, Krider and Day, 1943). It is of interest that the removal of the caecum led to a marked exacerbation of the symptoms of vitamin K deficiency, though rats from which the caecum had been removed, when receiving the basal diet without the sulphonamide, had only very mild symptoms (Day, Wakim, Krider and O'Bannion, 1943). It should be noted that the effect antagonistic to vitamin $K$ exercised by the coumarins, which is responsible for the haemorrhagic sweet clover disease, is not connected with bacterial action and that the coumarin acts when given parenterally (Overman, Field, Baumann and Link, 1942).

The appearance of leucopenia, granulocytopenia and anaemia in rats given sulphonamides has frequently been noted (Axelrod, Gross, Bosse and Swingle, 1943; Daft, Ashburn and Sebrell, 1942; Kornberg, Daft and Sebrell, 1943; Ransone and Elvehjem, 1943; Spicer, Daft, Sebrell and voL. 3,1945$]$ 
Ashburn, 1942; Totter and Day, 1943) and proved generally amenable to treatment with liver concentrates containing "folic acid", and, finally, with a crystalline preparation of "folic acid" (Daft and Sebrell, 1943). The efficacy of xanthopterin, the yellow pigment of butterfly wings, has been asserted (Totter and Day, 1943) and denied (Daft and Sebrell, 1943; Ransone and Elvehjem, 1943), but it is possible that the suggestion that xanthopterin may contribute a portion of the "folic acid" molecule (Wright and Welch, 1943, 2) may smooth out the difference. The interesting fact remains that in all probability the induced blood dyscrasia of rats is either closely related to, or identical with, the disease appearing spontaneously in monkeys receiving purified diets, which has been extensively studied in this country by Wills and her collaborators (Wills, Clutterbuck and Evans, 1937; Wills and Stewart, 1935), and in the States by Day and his colleagues (Day, Langston and Darby, 1938; Langston, Darby, Shukers and Day, 1938; Day, Langston, Darby, Wahlin and Mims, 1940; Day, Langston and Shukers, 1935; Totter, Shukers, Kolson, Mims and Day, 1944). It may be added, to illustrate differences between species, that, in the dog, the administration of sulphonamides does not interfere in any way with the regeneraton of haemoglobin (Michaud, Maass, Ruegamer and Elrohjem, 1944).

Of other deficiency states induced by sulphonamides I might mention biotin deficiency (Daft, Ashburn and Sebrell, 1942; Martin, 1942, 2; Nielsen and Elvehjem, 1942; Neumann, Krider and Day, 1943; Emerson. and Wurtz, 1944), inositol deficiency (Nielsen and Black, 1944), vitamin E deficiency (Daft, Endicott, Ashburn and Sebrell, 1943) and pantothenic acid deficiency (West, Jefferson and Rivera, 1943; Wright and Welch, $1943,1)$. The deficiency produced by the last named authors, though proved by a marked reduction in the liver reserves of pantothenic acid, could not be cured by its administration but yielded to treatment with biotin and a "folic acid" concentrate, with concomitant rise in the level of pantothenic acid in the liver. Such findings demonstrate the great complexity of the intestinal relationships of various, often not sufficiently defined, factors and underline the need for caution and discrimination in their interpretation.

It should be made elear that the administration of para-aminobenzoic acid to rats counteracts the effects of sulphonamides. The antagonism is very obvious with sulphaguanidine (Black, McKibbin and Elvehjem, 1941; Mackenzie, Mackenzie and McCollum, 1941), but much less marked with succinyl-sulphathiazole (Day, Wakim, Krider and O'Bannion, 1943; Martin, 1942, 1; Neumann, Krider and Day, 1943; Welch, 1942; Welch and Wright, 1943). The difference is probably rather of degree than in mode of action.

Though I am probably trespassing on Dr. Smith's preserves I may be forgiven for bringing to your attention the observation by Martin (1944) that a mixture of pure amino-acids adequate as a protein substitute for rats becomes inadequate in the presence of succinyl-sulphathiazole, and the cognate findings of West, Jefferson and Rivera (1943) of a beneficial effect of $l$-cystine and $d l$-methionine on a condition brought about in rats by giving sulphonamide with a diet low in casein.

The view that these manifold effects are the expression of changes in the synthesizing powers of intestinal bacteria is supported by the results 
of experiments in which the growth of rats on a synthetic diet was inhibited by giving sulphaguanidine, and restored by addition of faeces of rats receiving the synthetic diet alone but not of faeces. of rats given also the sulphonamide. Examination of the flora indicated no notable decrease in the total count but an alteration in composition (Light, Cracas, Olcott and Frey, 1942). Other workers (Gant, Ransone, McCoy and Elvehjem, 1943; Marshall, Bratton, White and Litchfield, 1940; White, 1942) noticed a drop in the numbers of Bact.coli in the intestine of rats and mice. When the drop was temporary (Gant, Ransone, McCoy and Elvehjem, 1943) the return of the coli count to normal was probably an expression of adaptation of the micro-organisms to the drug (Vivino and Spink, 1942; Woolley, 1944) though possibly with loss of ability to synthesize certain essential factors. According to Miller (1944), however, diminished synthesis is directly due to the presence of the sulphonamide in the intestine.

It is striking that the order of effectiveness of various sulphonamides in producing a deficiency of vitamin K (Kornberg, Daft and Sebrell, 1944) is very similar to the order of activity of the drug in depressing the numbers of coliform organisms in the intestines of the mouse (White, 1942).

\section{Synthesis by Human Beings}

Recent work shows that symbiotic synthesis may play a part in the vitamin economy of man. It is known for example that the amount of biotin excreted in the urine and faeces may be 3 to 6 times greater than the intake from a uniform diet (Oppel, 1942). More direct evidence is available regarding the manufacture of vitamin $B_{1}$ by intestinal bacteria, and the contribution of this source to the vitamin $B_{1}$ requirements of man (Najjar and Holt, 1943). Thus, 9 adolescent males received a synthetic diet free from vitamin $B_{1}$ but supplemented with small amounts of the vitamin which were gradually reduced until the men subsisted for months on an amount between 0.1 and $0.2 \mathrm{mg}$. daily without shawing any clinical or laboratory symptoms of deficiency other than the excretion in the urine of only negligible quantities of the vitamin. When this was omitted altogether from the diet, 4 of the 9 subjects developed in the next 3 to 5 weeks definite clinical evidence of deficiency, neuritis or oedema associated with anorexia and, sometimes, vomiting, l subject had questionable symptoms and the remaining 4 showed no signs of deficiency during 7 weeks of observation. While not more than traces of free vitamin $B_{1}$ were detected in the faeces of the deficient subjects, much larger quantities were found in the stools of those who remained without symptoms; moreover, the administration to one of them of succinylsulphathiazole promptly reduced his faecal output of free vitamin $B_{1}$. The correlation of the symptoms with the excretion of combined vitamin $B_{1}$ was much less satisfactory. As a final link in this interesting experiment, the ability of the large intestine in man to absorb vitamin $B_{1}$ was demonstrated by a marked increase in the urinary excretion of this factor after its administration by retention enemas.

Similar observations with riboflavin have been published very recently from the same laboratory (Najjar, Johns, Medairy, Fleischmann and Holt, 1944). Twelve youths received a synthetic diet supplying only 70 to $90 \mu \mathrm{g}$. of riboflavin daily and remained in excellent health throughout voL. 3,1945 ] 
the 3 months of the study. The urinary excretion amounted to 150 to $250 \mu \mathrm{g}$. daily, while 200 to $600 \mu \mathrm{g}$. were excreted daily in the faeces. Again the ability of the large intestine to absorb riboflavin was demonstrated by the enema technique but, surprisingly enough, the administration of succinyl-sulphathiazole did not reduce the riboflavin output in the stools though it promptly inhibited the faecal excretion of vitamin $B_{1}$.

Noteworthy findings concerning the economy of niootinic acid have also come to hand (Ellinger and Coulson, 1944; Ellinger, Coulson and Benesch, 1944). These authors observed that the excretion of this factor usually considerably outweighed the consumption and that the administration of succinyl-sulphathiazole was followed by a marked decrease in the output. Calculations indicated that the quantity of nicotinic acid provided by the bacterial flora for human utilization may amount to 80 per cent. of the daily uptake. Ellinger, Coulson and Benesch point out that by the demonstration of bacterial synthesis of nicotinic acid in man the paradoxes of the known pellagra preventive action of milk and milk products which are notoriously poor in nicotinic acid, and of the fact that maize, which is not more deficient than wheat, is the staple food in districts where pellagra is endemic, may be explained by assuming a primary effect of these foods on the intestinal flora and on the endogenous synthesis of nicotinic acid.

All these highly revolutionary observations certainly cast doubt on the suggested or accepted norms of requirements for various vitamins, often unduly high; they also help to explain many discrepancies and differences of opinion in this matter. The study of this important field is, however, still in its very early stages and one would do well to guard against going to the other extreme and placing too much reliance on possibilities of symbiotic self sufficiency of man.

\section{REFERENCES}

Abdel-Salaam, A. and Leong, P. C. (1938). Biochem. J. 32, 958.

Axelrod, A. E., Gross, P., Bosse, M. D. and Swingle, K. F. (1943). J. biol. Chem. 148, 721.

Bechdel, S. I., Eckles, C. H. and Palmer, L. S. (1926). J. Dairy Sci. 9, 409.

Bechdel, S. I. and Honeywell, H. E. (1927). J. agric. Res. 35, 283.

Bechdel, S. I., Honeywell, H. E., Dutcher, R. A. and Knutsen, M. H. (1927). Bull. Pa agric. Exp. Sta. no. 213, p. 17.

Bechdel, S. I., Honeywell, H. E., Dutcher, R. A. and Knutsen, M. H. (1928). J. biol. Chem. 80, 231.

Black, S., McKibbin, J. M. and Elvehjem, C. A. (1941). Proc. Soc. exp. Biol., N.Y., 47, 308.

Black, S., Overman, R. S., Elvehjem, C. A. and Link, K. P. (1942). J. biol. Chem. 145, 137.

Bliss, S. (1936). J. Nutrit. 11, 1.

Burkholder, P. R. and MeVeigh, I. (1942). Proc. nat. Acad. Sci., Wash., 28, 285.

Daft, F. S., Ashburn, L. L. and Sebrell, W. H. (1942). Science, 96, 321.

Daft, F. S., Ashburn, L. L., Spicer, S. S. and Sebrell, W. H. (1942). Publ. Hlth Rep., Wash., 57, 217.

Daft, F. S., Endicott, K. M., Ashburn, L. L. and Sebrell, W. H. (1943). Proc. Soc. exp. Biol., N.Y., 53, 130.

Daft, F. S. and Sebrell, W. H. (1943). Publ. Hlth Rep., Wash., 58, 1542.

Dam, H., Schønheyder, F. and Lewis, L. (1937). Biochem. J. 31, 22.

Dann, W. J. (1941). J. biol. Chem. 141, 803.

Day, H. G., Wakim, K. G., Krider, M. M. and O'Bannion, E. E. (1943). J. Nutrit. $26,585$.

Day, P. L., Langston, W. C. and Darby, W. J. (1938). Proc. Soc. exp. Biol., N.Y., 38, 860 . 
Day, P. L., Langston, W. C., Darby, W. J., Wahlin, J. G. and Mims, V. (1940). J. exp. Med. 72, 463.

Day, P. L., Langston, W. C. and Shukers, C. F. (1935). J. Nutrit. 9, 637.

Eden, A. (1940, 1). Nature, Lond., 145, 36.

Eden, A. $(1940,2)$. Nature, Lond., 145, 628.

Eijkman, C. (1897). Virchows Arch. 148, 523.

Ellinger, P. and Coulson, R. A. (1944). Biochem. J. 38, 265.

Ellinger, P., Coulson, R. A. and Benesch, R. (1944). Nature, Lond., 154, 270.

Emerson, G. A. and Tishler, M. (1944). Proc. Soc. exp. Biol., N.Y., 55, 184.

Emerson, G. A. and Wurtz, E. (1944). Proc. Soc. exp. Biol., N.Y., 57, 47.

Fildes, P. (1940). Lancet, 238, 955.

Fridericia, L. S. (1926). Skand. Arch. Physiol. 49, 55.

Fridericia, L. S., Freudenthal, P., Gudjonsson, S., Johansen, G. and Schoubye, N. (1927-28). J. Hyg., Camb., 27, 70.

Gant, O. K., Ransone, B., McCoy, E. and Elvehjem, C. A. (1943). Proc. Soc. exp. Biol., N.Y., 52, 276.

Greaves, J. D. (1939). Amer. J. Physiol. 125, 429.

Griffith, W. H. (1935). J. Nutrit. 10, 675.

Guerrant, N. B., Dutcher, R. A. and Tomey, L. F. (1935). J. biol. Chem. 110, 233.

Hart, E. B., Steenbock, H., Humphrey, G. C. and Hulce, R. S. (1924-25). J. biol. Chem. 62, 315.

Henry, R. J. (1943). Bact. Rev. 7, 175.

Hopkins, F. G. (1912). J. Physiol. 44, 425.

Hopkins, F. G. (1944). Proc. Nutr. Soc. 1, 3.

Hunt, C. H., Burroughs, E. W., Bethke, R. M., Schalk, A. F. and Gerlaugh, P. (1943). J. Nutrit. 25, 207.

Hunt, C. H., Kick, C. H., Burroughs, E. W., Bethke, R. M., Schaik, A. F, and Gerlaugh, P. (1941). J. Nutrit. 21, 85 .

Hurst, A. F. and Knott, F. A. (1930). J. Physiol. 70, xxxvii.

Johnson, P., Maynard, L. A. and Loosli, J. K. (1941). J. Dairy Sci. 24, 57.

Kelly, E. and Parsons, H. T. (1937). J. Nutrit. 13, 453.

Knight, B. C. J. G. (1944). Proc. R. Stoc. Med. 37, 492.

Kon, P. M. (1935). A Bacteriological and Physiological Study of the Phenomenon of Potato Stareh Refection in the Rat. Ph.D. Thesis. University of Reading.

Kon, P. M., Kon, S. K. and Mattick, A. T. R. (1938). J. Hyg., Camb., 38, I.

Kon, S. K. (1931). J. Hyg., Camb., 31, 543.

Kon, S. K. and Watchorn, E. (1927-28). J. Hyg., Camb., 27, 321.

Kornberg, A., Daft, F. S. and Sebrell, W. H. (1943). Science, 98, 20.

Kornberg, A., Daft, F. S. and Sebrell, W. H. (1944). Publ. Hlth Rep., Wash., 59,832 .

Langston, W. C., Darby, W. J., Shukers, C. F. and Day, P. L. (1938). J. exp. Med. 68, 923 .

Langworthy, C. F. and Deuel, H. J., Jr. (1920). J. biol. Chem. 42, 27.

Lardinois, C. C., Mills, R. C., Elvehjem, C. A. and Hart, E. B. (1944). J. Dairy Sci. 27, 579.

Light, R. F., Cracas, L. J., Olcott, C. T. and Frey, C. N. (1942). J. Nutrit. 24, 427.

Lundquist, N. S. and Phillips, P. H. (1943). J. Dairy Sci. 26, 1023.

MeEIroy, L. W. and Goss, H. (1939). J. biol. Chem. 130, 437.

MeElroy, L. W. and Goss, H. (1940, 1). J. biol. Chem. 133, lxv.

McEIroy, L. W. and Goss, H. $(1940,2)$. J. Nutrit. 20, 527.

McElroy, L. W. and Goss, H. $(1940,3)$. J. Nutrit. 20, 541 .

MeElroy, L. W. and Goss, H. (1941, 1). J. Nutrit. 21, 163.

McElroy, L. W. and Goss, H. $(1941,2)$. J. Nutrit. 21, 405.

MeElroy, L. W. and Jukes, T. H. (1940). Proc. Soc. exp. Biol., N.Y., 45, 296.

Mcllwain, H. (1940). Brit. J. exp. Path. 21, 136.

McIlwain, H. (1942). Brit. J. exp. Path. 23, 95.

Mackenzie, J. B., Mackenzie, C. G. and MeCollum, E. V. (1941). Science, 94, 518.

Madsen, H. (1939). Nature, Lond., 143, 981.

Mannering, G. J., Orsini, D. and Elvehjem, C. A. (1944). J. Nutrit. 28, 141.

Marshall, E. K., Bratton, A. C., White, H. J. and Litchfield, J. T., Jr. (1940). Johns Hopk. Hosp. Bull. 57, 163.

Martin, G. J. $(1942,1)$. Proc. Soc. exp. Biol., N.Y., 51, 56.

Martin, G. J. (1942, 2). Proc. Soc. exp. Biol., N.Y., $51,353$.

Martin, G. J. (1944). Proc. Soc. exp. Biol., N.Y., 55, 182.

voI. 3,1945$]$ 
Michaud, L., Maass, A. R., Ruegamer, W. R. and Elvehjem, C. A. (1944). Proc. Soc. exp. Biol., N.Y., 56, 148.

Miller, A. K. (1944). Proc. Soc. exp. Biol., N.Y., 57, 151.

Mitchell, H. K. and Isbell, E. R. (1942). Univ. Tex. Publ. no. 4237, p. 125.

Morgan, A. F., Cook, B. B. and Davison, H. G. (1938). J. Nutrit. 15, 27.

Morot, C. (1882). Mém. Soc. Méd. vét. 12, Ser. 1.

Najjar, V. A. and Holt, L. E., Jr. (1943). J. Amer. med. Ass. 123, 683.

Najjar, V. A., Johns, G. A., Medairy, G. C., Fleischmann, G. and Holt, L. E., Jr. (1944). J. Amer. med. Ass. 126, 357.

Nathan, M. (1935). Undersøgelser over Refehtion. Copenhagen: Levin og Munksgaard.

Neumann, F. W., Krider, M. M. and Day, H. G. (1943). Proc. Soc. exp. Biol., N.Y., 52, 257.

Nielsen, E. and Black, A. (1944). Proc. Soc. exp. Biol., N.Y., 55, 14.

Nielsen, E. and Elvehjem, C. A. (1942). J. biol. Chem. 145, 713.

Nielsen, E., Shull, G. M. and Peterson, W. H. (1942). J. Nutrit. 24, 523.

Oppel, T. W. (1942). Amer. J. med. Sci. 204, 856; 863; 869.

Orla-Jensen, S., Orla-Jensen, A. D., Dam, H. and Glavind, J. (1941). Zbl. Bakt. Abt. 2, 104, 202.

Osborne, T. B. and Mendel, L. B. (1911). Publ. Carneg. Instn, no. 156, part 2, p. 59.

Osborne, T. B. and Mendel, L. B. (1918). J. biol. Chem. 34, 537.

Osborne, T. B. and Mendel, L. B. (1920). J. biol. Chem. 41, 515.

Overman, R. S., Field, J. B., Baumann, C. A. and Link, K. P. (1942). J. Nutrit. 23,589 .

Parsons, H. T. and Kelly, E. (1935). Int. physiol. Congr. 15, Leningrad-Moscow. Summaries of Communications, p. 310.

Parsons, H. T., Kelly, E. and Hussemann, D. L. (1933). J. biol. Chem. 100, lxxvi.

Pearson, P. B., Schmidt, H. and Mackey, A. K. (1939). Proc. Soc. exp. Biol., N.Y., 40, 423.

Phillips, P. H., Lundquist, N. S. and Boyer, P. D. (1941). J. Dairy Sci. 24, 977.

Randoin, L. and Lecoq, R. (1927). J. Pharm. Chim., Paris, 5, 147.

Randoin, L. and Simonnet, H. (1923). C.R. Acad. Sci., Paris, 177, 903.

Randoin, L. and Simonnet, H. (1924, 1). Bull. Soc. sci. Hyg.aliment., Paris, 12, 86.

Randoin, L. and Simonnet, H. (1924, 2). Bull. Soc. Chim. biol., Paris, 6, 601.

Randoin, L. and Simonnet, H. (1924, 3). C.R. Acad. Sci., Paris, 178, 963.

Randoin, L. and Simonnet, H. (1924, 4). C.R. Acad. Sci,, Paris, 179, 700.

Randoin, L. and Simonnet, H. (1924, 5). C.R. Acad. Sci., Paris, 179, 1219.

Randoin, L. and Simonnet, H. (1925). Bull. Soc. Chim. biol., Paris, 7, 678.

Ransone, B. and Elvehjem, C. A. (1943). J. biol. Chem. 151, 109.

Robinson, F. A. (1944). Chem. and Ind. p. 370.

Roseoe, M. H. (1927-28). J. Hyg., Camb., 27, 103.

Savage, E. S. and McCay, C. M. (1942). J. Dairy Sci. 25, 595.

Schaefer, A. E., McKibbin, J. M. and Elvehjern, C. A. (1942). J. biol. Chem. 144, 679 .

Scheunert, A. and Schieblich, M. (1927). Liebigs. Ann. 453, 249.

Snell, E. E. (1941). J. biol. Chem. 141, 121 .

Snell, E. E., Chan, L., Spirodanoff, S. and Way, E. L. (1943). Fed. Proc. $2,92$.

Spicer, S. S., Daft, F. S., Sebrell, W. H. and Ashburn, L. L. (1942). Publ. Hlth Rep., Wash., 57, 1559.

Taylor, A., Pennington, D. and Thacker, J. (1942). Univ. Tex. Publ. no. 4237, p. 135 .

Taylor, E. L. (1939). Nature, Lond., 143, 982.

Taylor, J. and Thant, U. (1929). Indian J. med. Res. 16, 747.

Theiler, A., Green, H. H. and Viljoen, P. R. (1915). Rep. vet. Res. S. Afr. 3 and 4, 9.

Thompson, R. C. (1942). Univ. Tex. Publ. no. 4237 , p. 87.

Totter, J. R. and Day, P. L. (1943). J. biol. Chem. 147, 257.

Totter, J. R., Shukers, C. F., Kolson, J., Mims, V. and Day, P. L. (1944). $J$. biol. Chem. 152, 147.

Unna, K. (1943). Proc. Soc. exp. Biol., N.Y., 54, 55.

Vivino, J. J. and Spink, W. W. (1942). Proc. Soc. exp. Biol., N.Y., 50, 336.

Wakim, K. G., Krider, M. M. and Day, H. G. (1943). Proc. Soc. exp. Biol., N.Y., 54,164 .

Wegner, M. I., Booth, A. N., Elvehjem, C. A. and Hart, E. B. (1940). Proc. Soc. exp. Biol., N.Y., 45, 769 . 
Wegner, M. I., Booth, A. N., Elvehjem, C. A. and Hart, E. B. (1941). Proc, Soc. exp. Biol., N.Y., 47, 90.

Welch, A. D. (1942). Fed. Proc. 1, 171.

Welch, A. D. and Wright, L. D. (1943). J. Nutrit. 25, 555.

West, H. D., Jefferson, N. C. and Rivera, R. E. (1943). J. Nutrit. 25, 471.

West, R. (1941). Proc. Soc. exp. Biol., N.Y., 46, 369.

White, H. J. (1942). Johns Hopk. Hosp. Bull. 71, 213.

Wills, L., Clutterbuck, P. W. and Evans, B. D. F. (1937). Biochem. J. 31, 2136.

Wills, L. and Stewart, A. (1935). Brit. J. exp. Path. 16, 444.

Woods, D. D. (1940). Brit. J. exp. Path. 21, 74.

Woolley, D. W. (1942). J: exp. Med., 75, 277.

Woolley, D. W. (1944). Proc. Soc. exp. Biol., N.Y., 55, 179.

Woolley, D. W. and White, A. G. C. $(1943,1)$. J. biol. Chem. 149, 285.

Woolley, D. W. and White, A. G. C. $(1943,2)$. Proc. Soc. exp. Biol., N.Y., 52, 106.

Wright, L. D. and Welch, A. D. $(1943,1)$. Science, 97, 426.

Wright, L. D. and Welch, A. D. $(1943,2)$. Science, 98, 179.

\section{Discussion}

Dr. L. J. Harris (Dunn Nutritional Laboratory, Cambridge), opener: After Dr. Kon's very thorough and clear review, I desire to confine myself to the single topic of refection as a factor which may influence the accuracy of vitamin tests. I shall deal with this in the following summarized statements.

(1) Conditions obviously vary considerably from one laboratory to another. As has been pointed out, refection is a commonplace occurrence in some centres while in others it has been rarely or never observed.

(2) It so happens that in our institute at Cambridge refection has been of very common occurrence. Moreover, it has been seen not only with diets containing potato starch and sometimes rice starch, but also, at various times, with most types of raw, and even cooked, starchy foods, including wheat flours and breads.

(3) Its incidence has been so erratic, however, that we can never predict the percentage of animals which may become refected, or fail to do so, on a particular diet. Sometimes it may be all or nearly all which get refected, sometimes scarcely any.

(4) It is obvious from this that when we are testing substances biologically for B vitamins by means of growth tests on rats, refection may introduce an unpredictable variable, which can sometimes upset results in a haphazard manner, if starch is present in the basal diet. That is to say, the rat may be receiving its own secret supply of B vitamins, made by its alimentary microflora, irrespective of the amount in the dose of the foodstuff under test, and of the absence of any from the basal diet.

(5) Because of this experience, we abandoned the use of starch in our basal diets many years ago, and now use sugar as the only source of carbohydrate in vitamin $B$ tests.

(6) A further problem arises, however, when the material under test, as distinct from the basal diet, is itself rich in starch. For example, we found we could not make satisfactory comparisons of vitamin $B_{1}$ in different types of wheat flours and breads by means of growth tests on rats, because of this erratic occurrence of refection (Harris, 1937).

(7) We were able to obviate this last difficulty by using other methods of biological test in place of growth tests, namely, the bradycardia test on rats (Birch and Harris, 1934; Harris, 1934; Leong and Harris, 1937; Harris and Wang, 1941), or a method employing the cure of convulsions. voc. 3, 1945] 
With these methods a single test dose only of the material to be examined has to be given to the rats, instead of daily supplements continued over long periods as with the growth test. Consequently, in the relatively few hours during which the test lasts, refection has little or no chance to become established.

Passing reference may be made to another technique which has recently become possible, in which refective processes can be inhibited by the use of sulphonamide drugs or other bacteriostatic agents.

(8) Finally, I should like to add that my own observations are entirely in accord with those of Dr. Kon about the reality of, and, as I believe, the importance of, what I have termed low grade refection, or incipient refection or various partial degrees of refection. Indeed it seems obvious that under normal conditions there must always be some small and variable amount of bacterial synthesis of $B$ vitamins, although admittedly, the amount absorbed by the rat is generally too small to be of much practical consequence, except perhaps when potato starch, recognized as favourable to refection, is employed in the basal diet.

Curves of rat growth can be selected to exemplify the conditions experienced at the Dunn Nutritional Laboratory, Cambridge, and to illustrate such points as the following: $(a)$ The variable and erratic incidence of refection on various diets; $(b)$ the increased weight gains on basal diets containing potato starch as compared with rice starch or sugar; (c) the extent to which an average curve for a group of animals may be determined entirely by the occurrence or absence of sporadic instances of refection within the group; $(d)$ the occurrence of cases of intermittent refection or of minor degrees of refection, marked by only partial recovery and by indifferent and irregular growth, as contrasted with the precipitate fall in weight and early death seen in deficient nonrefected animals on the one hand, and the dramatic recovery and good gain in growth seen in the fully refected animal on the other hand.

REFERENCES

Birch, T. W. and Harris, L. J. (1934). Biochem. J. 28, 602.

Harris, L. J. (1934). J. agric. Sci. 34, 410.

Harris, L. J. (1937). Biochem. J. 31, 799.

Harris, L. J. and Wang, Y. L. (1941). Biochem. J. 35, 1050.

Leong, P. C. and Harris, L. J. (1937). Biochem. J. 31, 812.

Dr. A. Eden (School of Agriculture, Cambridge): Some years ago we were carrying out at the Veterinary Laboratory at Weybridge some investigations on the metabolism of copper in the body, using rabbits as convenient experimental animals, and were rather puzzled by the apparent slowness with which copper was excreted from the alimentary tract. In some cases 30 days were needed for the complete excretion of a single dose of the element and for the return of the faecal concentration of copper to the normal, characteristic of the basal diet. Direct and indirect evidence showed that the copper was not retained in the body and was not adsorbed on the walls of the gut, and it was difficult to explain the very slow rates of elimination.

About this time Madsen (1939) drew attention to an early observation by Morot (1882) that the rabbit normally passes 2 types of faeces, one the ordinary, comparatively dry pellet type and the other, at night, consisting of large mulberry like masses of much wetter material, the so 
called night faeces. These latter are rarely observed in the ordinary way as the rabbit takes them direet from its anus and swallows them whole. Taylor (1939) confirmed the observations and, by muzzling his animals at night, succeeded in collecting specimens of the night faeces. He gave the name of pseudo-rumination to this process, without suggesting for it any specific function, but we realized that the long delayed excretion of copper in previous experiments was due to this cycle and called it "physiological faecal refection" as it was undoubtedly a regular and definite physiological habit of the rabbit. The phenomenon was so interesting in itself that it was decided to obtain more quantitative data by a series of balance experiments (Eden, 1940, 1, 2).

After some trial and error we had a wooden collar constructed which, when placed round a rabbit's neck in the metabolism cage, would prevent its taking faeces from its anus but would allow it to rest and eat normally. The rabbit was given a definite amount of a diet of equal parts of bran and oats and next morning we were able to collect considerable amounts of these soft mulberry faeces from the cages. The experiments were continued on a quantitative basis with alternate periods with and without the collar, the day faeces being of the normal type and those passed sometime during the night being of the characteristic night type. Careful observation of the various habits of the rabbit showed that ordinary coprophagy goes on even during the day. By quantitative measurements of the amounts of dry matter excreted it was possible to calculate that the rabbit may normally re-consume between 50 and 90 per cent. of the total faeces passing the anus each day, and a rabbit wbich, uncollared, excreted an average of $9.5 \mathrm{~g}$. dry matter each day, actually voided $54.5 \mathrm{~g}$. dry matter in a 24-hour period after collaring; $37.5 \mathrm{~g}$. of this dry matter was in the ordinary day faeces and $17 \mathrm{~g}$. in the softer night faeces.

The 2 types of faeces differ considerably in chemical composition. On a dry matter basis the conventional agricultural analyses were as given in Table 1.

TABLE I

Percentage Chemical Composition of the food and of the Day and Night Faeces of the Rabbit

\begin{tabular}{|c|c|c|c|c|}
\hline Constituent & & Food & Day faeces & Night faeces \\
\hline 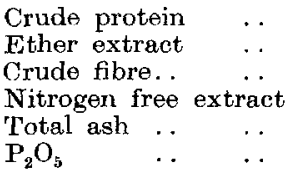 & \begin{tabular}{l|}
$\cdots$ \\
$\cdots$ \\
$\cdots$ \\
$\cdots$ \\
$\cdots$
\end{tabular} & $\begin{array}{r}14 \cdot 7 \\
5 \cdot 2 \\
11 \cdot 7 \\
63 \cdot 6 \\
4 \cdot 8 \\
2 \cdot 1\end{array}$ & $\begin{array}{r}9 \cdot 2 \\
1 \cdot 7 \\
28 \cdot 9 \\
52 \cdot 0 \\
8 \cdot 2 \\
2 \cdot 9\end{array}$ & $\begin{array}{r}28 \cdot 5^{*} \\
1 \cdot 1 \\
15 \cdot 5 \\
43 \cdot 7 \\
11 \cdot 2 \\
5 \cdot 0\end{array}$ \\
\hline
\end{tabular}

* $25 \cdot 8$ per cent. true protein.

It was difficult to sec how 2 types of faeces differing so widely in chemical composition could be passed regularly every 24 hours on a diet of constant composition but, remembering that the rabbit possesses an enormous caecum, we wondered if the night faeces were derived from this organ. A rabbit was collared overnight and night faeces collected; next morning it was killed and the caecal contents analysed. The analysis voc. 3, 1945] 
showed a striking similarity in the composition of the caecal contents and of the night faeces (Table 2).

TABLE 2

Percentage Chemical Composition of Caecal Contents and Night Faeces of the Rabbit

\begin{tabular}{|c|c|c|}
\hline Constituent & Caecal contents & Night faeces \\
\hline 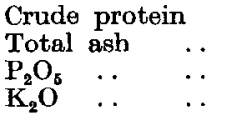 & $\begin{array}{r}39 \cdot 9 \\
11 \cdot 2 \\
4 \cdot 4 \\
1 \cdot 2\end{array}$ & $\begin{array}{r}30 \cdot 0 \\
11 \cdot 1 \\
4 \cdot 2 \\
1 \cdot 7\end{array}$ \\
\hline
\end{tabular}

From these data a general explanation of the daily rhythm of the intestine of the rabbit can be made. As the contents pass through the tract towards the large intestine, part fills into the caecum and part goes directly along the colon and rectum and is voided as normal faeces. That portion which goes into the caecum has a comparatively long sojourn there, up to 24 hours, during which time it is attacked by the large mass of bacteria present which flourish on this pabulum. Here go on simultaneously processes of synthesis and breakdown, perhaps not dissimilar from those taking place in the paunch of ruminants. During the night the contents of the caecum are rapidly discharged into the colon and rectum without undergoing the processes of inspissation occurring with normal faeces. They are then swallowed directly by the rabbit and once more pass the length of the alimentary tract undergoing the normal processes of digestion. In this way some of the initial food residues which would otherwise have been lost to the animal are, as it were, given a second extraction. So far we have little direct knowledge of the nature of the bacteria in the caecum but presumably the crude fibre portion of the ration is partially broken down and rendered available to the animal in its second passage through the gut. By determining the standard digestibility coefficients of the constituents of an oats and bran diet given to a rabbit, with and without a collar, we found that the crude fibre fraction was digested to an extent 20 per cent. greater when the normal process of physiological refection was allowed to occur. It is probable also that the action of the caecal bacteria is to build up or synthesize certain vitamins and other accessory food factors, but this awaits direct experimental proof.

The resemblance of this peculiar process in the rabbit to that of rumination in the 4-stomached herbivora is striking. In a teleological sense, it may be that this process of refection of faeces was evolved to help to tide the animal over periods of food shortage in the natural state and, besides reducing the actual hunger cravings, also may supply certain essential food factors absent from the natural diet but synthesized by the caecal bacteria. It is possible that further biochemical and physiological studies of this interesting habit might throw more light on the comparatively little known functions of the caecum in animals including man, and extend our knowledge of the part played by the microfauna of the alimentary tract. 
REEERENCES

Eden, A. (1940, 1). Nature, Lond., 145, 36.

Eden, A. $(1940,2)$. Nature, Lond., 145, 628.

Madsen, H. (1939). Nature, Lond., 143, 981.

Morot, C. (1882). Mém. Soc. Méd. vét. 12, Ser. 1.

Taylor, E. L. (1939). Nature, Lond., 143, 982.

Professor L. S. Fridericia (Institute of Hygiene, University of Copenhagen*): I am very grateful for the invitation to take part in today's meeting. The problems discussed have interested me for many years and I should like to mention some investigations carried out in the Copenhagen University Institute of Hygiene and published in Scandinavian periodicals, partly in the Danish language.

It is generally supposed that the synthesis of vitamins of the B group in the alimentary tract is carried out by the intestinal bacteria. This supposition is probably true. I have no other to offer, but, if the common intestinal bacteria of men, rats or pigeons were able under their usual conditions to synthesize the B vitamins one would never see any symptoms of "vitamin B" deficiency. That is to say, when B vitamins are synthesized in the alimentary tract of animals, susceptible to the deprivation, there must be something special about either the synthesizing bacteria or the conditions in the intestinal tract.

In the Copenhagen investigations on refection in rats we have never been able to prove that specific micro-organisms had to be present when vitamin $B$ was synthesized in the intestines. We have striven hard to find such specific micro-organisms but without success. It was mentioned in our first publications that many gram negative vibrios were always present in refected rats (Fridericia, 1926; Fridericia, Freudenthal, Gudjonsson, Johansen and Schoubye, 1927-28). These vibrios were later seen and described by Schieblich (1929) in Leipzig, but neither in Copenhagen nor in Leipzig could the vibrios be cultivated. These vibrios are found not only in the caecum and colon of refected rats. Dr. Mogens Nathan (1935) in Copenhagen found multitudes of gram negative vibrios in aspirated stomach contents of living refected rats, but he found a few of the vibrios in the aspirated stomach contents also of normal rats. Nothing more is known about these vibrios.

It is known that many bacteria are able to synthesize vitamin $B_{1}$ and other vitamins of the B group. Some investigators have found that common intestinal bacteria of man and rat are able to carry out this synthesis. If the synthesizing bacteria are not specific, there must be something specific about the conditions existing in the intestinal tract during refection. Scheunert and Schieblich (1927) showed in Leipzig that the $p \mathrm{H}$ of the culture medium decided whether or not $B$. vulgatus Migula could synthesize vitamin $B_{1}$. They thought the same applied to Bact. coli.

The question then arises whether there is anything specific about the $p \mathrm{H}$ of the intestinal contents of the rat during refection. Kon, Kon and Mattick (1938) have recently published valuable investigations on this point. Also in Copenhagen this question has been examined. It was mentioned in the first publication concerning refection that the eaecal S.W.1.

* Temporary address: c/o Royal Danish Legation, 29 Pont Street, London,

vor. 3, 1945] 
contents of refected rats and of rats on normal diets are acid, the $p \mathrm{H}$ being 5.9 to 6.7 and 5.3 to 6.7 , respectively, while rats getting food mixtures devoid of "vitamin B" have in their caecum an alkaline reaction of $p \mathrm{H} \mathrm{7.7}$ to 8.7. At the 13th Nordic Medical Congress in Copenhagen in 1927 Dr. Niels Schoubye (1928) reported more detailed investigations which he had carried out in the Copenhagen University Institute of Hygiene on the $p \mathrm{H}$ in all parts of the intestinal tract of rats living on different diets. In the small intestine, he found with all diets a rise in $p \mathrm{H}$ from the pylorus to Bauhin's valve; more especially in the last portion of the ileum there was a regular change towards alkalinity. In rats on normal diets there was a sudden drop in $p \mathrm{H}$ at Bauhin's valve resulting in an acid reaction in the caecum. On the other hand, rats living on a diet deficient in $B$ vitamins and exhibiting symptoms of vitamin $B_{1}$ deficiency differed from animals on normal diets in having the highest $p \mathrm{H}$, that is to say the most alkaline reaction, in the caecum. Although they did not receive "vitamin B" in their food, refected rats behaved in this respect, as in others, like animals on normal diets, reaction changing from alkaline to acid at the Bauhin valve, just as in the normally nourished. There is nothing wrong with the $p \mathrm{H}$ in the caecum or elsewhere in the intestinal tract of refected rats. The $p \mathrm{H}$ measurements in normally nourished and refected rats do not indicate any difference in the intestinal content, looked upon as a nutrient medium for the intestinal bacteria, and the $p \mathrm{H}$ measurements accordingly do not explain why the $B$ vitamins are synthesized during refection and not normally.

There must be some difference, however, between the intestinal contents of normally nourished and refected rats. In the refected rats the intestinal contents must alter in such a way that they become a suitable medium for the synthesis of vitamins of the B group. This is essential. In his book Schopfer (1943) emphasizes that the capacity of micro-organisms for synthesis of vitamins is dependent upon external factors, both chemical and physical, that is to say upon the composition of the medium upon which they grow.

So far only one difference in composition is known between the in. testinal contents of normal and refected rats. That is the presence of undigested starch in the lower parts of the intestinal tract of refected rats. It is seen in all kinds of refection. In the Copenhagen experiments the rats got rice starch in their food. When refected, their faeces contained hetween 45 and 83 per cent. of starch. Kon and Watchorn (1927-28) discovered that refection may almost always be produced in rats by giving them potato starch in their food. The digestion of potato starch is defective and part of it reaches the caecum and colon and is found in the faeces. The gist of my remarks is, that I want to point out the probability of a connexion between the presence of starch and the occurrence of bacterial synthesis of vitamins of the B group in the intestinal tract of the rat. According to Hunt, Burroughs, Bethke, Schalk and Gerlaugh (1943) the same connexion obtains for the synthesis of vitamin $B_{1}$ and riboflavin in the rumen of cattle.

In Copenhagen the appearance of starch in the faeces of the refected rats raised a special problem because the food of the rats contained rice starch of which more than 99 per cent. is digested by normal rats, but only about 50 per cent. by refected. Why is the digestion of rice starch 
defective in refected rats? The most obvious surmise would be that the food passes more quickly through the intestinal tract of refected than of normal rats, but Dr. Gudjonsson (1927) in Copenhagen found that the rate of passage of food through the intestinal tract was about the same in normal and refected rats. The explanation turned out to be that the starch in the faeces of refected animals is more slowly dissolved by amylase than the starch in the food. This phenomenon was more closely investigated by Dr. Mogens Nathan (1935) in Copenhagen and the results were published in a comprehensive dissertation, which unfortunately is written in the Danish language but with an English summary. Dr. Nathan found that the digestibility by ptyalin of the washed rice starch from the faeces of refected rats was only between 21 and 48 per cent. of the digestibility of the rice starch in the food. The rice starch had thus been changed during the passage through the intestinal tract. The same is true of potato starch in the faeces of rats, refected by being given this kind of starch, for Dr. Nathan found that potato starch from the faeces of refected rats had only about 50 per cent. of the digestibility by ptyalin of potato starch from the food. $\mathrm{He}$ further found that the change in the digestibility of the starch took place before it reached the caecum. This may explain the rather surprising results of Dr. Kon's experiments concerning the effect of the removal of the caecum on the refection of rats, which he found to be without effect (Kon, 1935; Kon, Kon and Mattick, 1938). I return to my main point, that the presence of starch in the lower part of the intestinal tract seems to be necessary, if synthesis of vitamin $B_{1}$ and presumably other vitamins of the B group is to take place. When refected rats are given a diet containing sugar instead of starch, the refection disappears immediately. They must get starch, which is only partly digested, either potato starch or altered rice starch.

Very exciting is the question whether synthesis of vitamins of the $B$ group is possible in the intestinal tract of human beings. Last year Najjar and Holt (1943) published experiments with 9 men on a diet, gradually made devoid of vitamin $B_{x}$. They found that only 4 got symptoms of deficiency, while the faeces of the others contained considerable amounts of vitamin $B_{1}$ although the diet was devoid of it. These results suggest an explanation of the many clinical observations such as that of McCarrison about the irregular occurrence of beriberi in populations living on diets deficient in vitamin $B_{1}$. Unfortunately reliable estimations of vitamin $B_{1}$ in faeces are not easy to carry out. If the synthesis of vitamin $B_{1}$ can take place in the human intestinal tract, it remains to be investigated whether there is defective digestion of starch also in such cases.

\section{REFERENCES}

Fridericia, L. S. (1926). Skand. Arch. Physiol. 49, 55.

Fridericia, L. S., Freudenthal, P., Gudjonsson, S., Johansen, G. and Sehoubye, N. (1927-28). J. Hyg., Camb., 27, 70.

Gudjonsson, S. V. (1927). Hospitalstidende, 70, 1225.

Hunt, C. H., Burroughs, E. W., Bethke, R. M., Schalk, A. F. and Gerlaugh, P. (1943). J. Nutrit. 25, 207.

Kon, P. M. (1935). A Bacteriological and Physiological Study of the Phenomenon of Potato Starch Refection in the Rat. Ph.D. Thesis. University of Reading.

Kon, P. M., Kon, S. K. and Mattick, A. T. R. (1938). J. Hyg., Camb., 38, 1.

voL. 3, 1945] 
Kon, S. K. and Watchom, E. (1927-28). J. Hyg., Camb., 27, 321.

Najjar, V. A. and Hoit, L. E., Jr. (1943). J. Amer. med. Ass. 123, 683.

Nathan, M. (1935). Undersagelser over Refektion. Copenhagen: Levin og Munksgaard.

Scheunert, A. and Schieblich, M. (1927). Biochem. Z., 184, 58.

Schieblich, M. (1929). Biochem. Z. 207, 458.

Schopfer, W. H. (1943). Plants and Vitamins. Waltham, Mass., U.S.A.: The Chronica Botanica Co.

Schoubye, N. (1928). Acta med. Scand. 26, 537. Suppl.

Dr. G. Fraenkel (Biological Field Station, London Road, Slough, Bucks.): Certain insects which live on food of poor nutritive quality derive additional food factors from micro-organisms which live inside the cells of special organs. For instance, the larvae of 2 beetles grow well on an artificial diet supplemented with all the known factors of the vitamin $B$ complex in the pure form. Growth is still possible in the absence of most of these, though in certain instances at a reduced rate. If the intracellular symbiotic yeasts are experimentally removed no growth is possible in the absence of vitamin $\mathrm{B}_{1}$, riboflavin, nicotinic acid, vitamin $\mathrm{B}_{6}$, pantothenic acid or choline chloride (Blewett and Fraenkel, 1944).

\section{ReFERENCE}

Blewett, M. and Fraenkel, G. (1944). Proc. roy. Soc. (B), 132, 212.

Mr. A. L. Bacharach (Glaxo Laboratories, Ltd., Greenford, Middlesex): I would like to call attention to the bearing of riboflavin synthesis in the cow on the problems to be discussed at the Society's next meeting. The most economical use of wheat offals depends in part on the extent to which this foodstuff increases the nutritive value of milk from cows receiving it in their ration. If the high riboflavin content of milk is due to bacterial action in the rumen and is independent of the foodstuffs consumed, provided these are adequate, then this particular nutritive virtue cannot be credited to the offals.

In my laboratory we have never encountered refection, and this leads me to suggest a possible genetic factor which may even differentiate various strains of the same species. If refection can be produced in mice, they would form excellent experimental material for testing this hypothesis, for several genetically pure strains of mice are available in this country, whereas there is only one rigorously inbred strain of rats.

Dr. K. H. Coward (Pharmaceutical Society, at National Institute for Research in Dairying, University of Reading): My rat colony came originally from the Glaxo Laboratories, it has never been afflicted with refection.

Dr. H. M. Sinclair (Oxford Nutrition Survey, 10 Parks Road, Oxford): In clinical medicine there are 4 main conditions in which the intestinal microflora is of importance. Of these the synthesis of vitamin $K$ needs no comment. Nutritional deficiencies frequently arise after resection of the gut and in ulcerative colitis; probably failure of bacterial synthesis plays here a major part. Finally the use of sulphaguanidine for sterilizing the gut also may lead to nutritional deficiency of which the condition of agranulocytosis is an expression. 
Dr. S. K. Kon gave the following replies:

To Dr. Harris: The technique of inhibition of the refective processes by the administration of sulphonamide drugs mentioned by Dr. Harris promises to be of great value not only in facilitating trustworthy tests of members of the vitamin B complex, but also in the study of the phenomenon of refection itself. We have found that the addition of

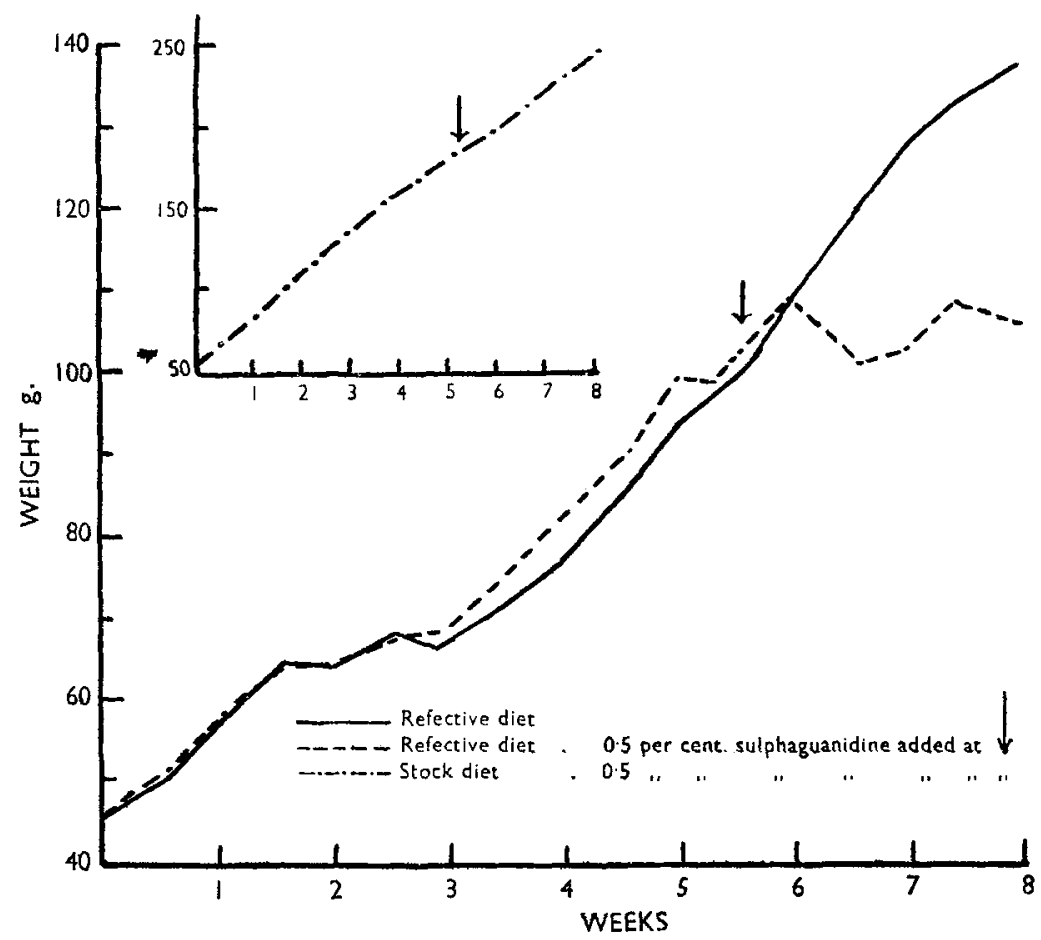

Figure 1. Embect on the Growth of Rmpected and Stock Rats of Adding Sulphaguanidine to the Diet.

0.5 per cent. of sulphaguanidine to our refective diet containing raw potato starch (Kon, Kon and Mattick, 1938) markedly inhibits the growth of well refected rats (Figure 1). We are investigating at present the immediate causes of this effect.

To Professor Fridericia: I entirely agree that the presence of undigested starch in the caecum is the most important pre-requisite of successful refection.

To Mr. Bacharach: There appears to be some connexion between the riboflavin content of milk and that of the fodder of the cow, but this is greatly obscured by the ruminal synthesis of riboflavin. We cannot honestly look upon the riboflavin of wheat offal as of importance in the maintenance of a satisfactory level of the vitamin in milk. Grass supplies more of it than the offal, yet the amount in milk fluctuates but little throughout the year.

vor. 3,1945$]$ 
Mr. Bacharach's other suggestion is worthy of consideration, but I have not heard of anyone producing refection in mice.

To Dr. Coward: Refection is an extremely eapricious phenomenon; while it may flourish in its various forms in one laboratory, as shown by Dr. Harris, it may resolutely refuse to appear in another. I have never had spontaneous rice starch refection in my laboratory even in the presence of well established potato starch refection.

REFERENCE

Kon, P. M., Kon, S. K. and Mattick, A. T. R. (1938). J. Hyg., Camb., 38, 1.

\section{The Production and Absorption of the Volatile Acids in the Rumen}

Mrs. R. A. Marshall and Dr. A. T. Phillipson (Agricultural Research Council Unit of Animal Physiology, Department of Physiology, Cambridge)

Gastric digestion, by which is usually understood peptic digestion, occurs only in the fourth part of the stomach of the ruminant. The suale on which this process proceeds is not known and it is in any case applicable only to protein. Apart from this question gastric digestion in the ruminant has a wider interpretation, since the rumen and reticulum together form an incubator in which the substrate is food, the digestive agents bacteria, and the end products of digestion, as far as is certainly ascertained, a mixture of the lower fatty acids together with methane. Gastric digestion in the ruminant therefore consists primarily of the fermentation of carbohydrate which is followed by true peptic digestion.

The scale on which fermentation in the rumen proceeds can be appreciated when the following points are considered.

(a) If grass is taken as a standard foodstuff, the carbohydrates eaten by ruminants, and indeed all herbivorous animals, are for the most part digestible only by the aid of bacteria. The ability of the ruminant to digest as much as 50 per cent. of the crude fibre of wheat straw and a higher proportion of the crude fibre of grass is indicative of the efficiency of the process of fermentation in the rumen.

(b) The caloric requirements of ruminants are obtained for the most part from the carbohydrate of the diet and, at grass, a $50 \mathrm{~kg}$. sheep will eat about $860 \mathrm{~g}$. carbohydrate a day of which about 75 per cent. is digested.

(c) The amount of ingesta found in the rumen and reticulum together forms a large proportion of the whole quantity of ingesta in the alimentary tract. In the sheep we have found the proportion contained in these 2 parts of the stomach to vary from 55 to 75 per cent. of the whole, while Washburn and Brodie (1937) obtained figures that exceed this range, their highest figure being 85 per cent. In the ox on the other hand the proportion is slightly less and 2 values we obtained were 40 and 42 per cent. This is due not to a smaller comparative capacity of the reticulum and rumen in the ox but to the increased capacity of the third part of the stomach, the omasum.

These 3 factors, the nature of the carbohydrates eaten, the quantity eaten, and the quantity of food contained in the reticulum and rumen 